\title{
PROFIL GEN RECEPTOR GROWTH HORMONE (rGH) PADA SAPI MADRASIN
}

\section{PROFIL GEN RESEPTOR GROWTH HORMONE (rGH) of MADRASIN COW}

\author{
Gigih Lesmana Arganata ${ }^{1)}$, *Budi Utomo S ${ }^{2)}$, R.T.S Adikara ${ }^{3)}$ \\ ${ }^{1)}$ Student, ${ }^{2)}$ Department of Veterinary Reproduction ${ }^{3)}$ Department of Veterinary Anatomy \\ Faculty of Veterinary Medicine, Universitas Airlangga \\ *Corresponding author: budi_reprovet@yahoo.com; gigih.lesmana1@gmail.com
}

\begin{abstract}
Cross-breeding between Madura cattle and exotic breeds (exotic cows) occurs in Madura area. The reality in the field shows that the cross-breeding occurs between Limousin cow and Madura cow and the result of the breeding is called as Madrasin cow. One of factor that influences the animal's growth is Growth Hormone Receptor (GHR). GHR is needed by Growth Hormone $(\mathrm{GH})$ to carry out its effects on target tissues. The purpose of this study is to identify the profile of Growth Hormone Receptors in Madrasin cow. This research was conducted on farmers in Bangkalan, East Java and the Center of Veterinary, Denpasar in MayJune 2017. This study used 14 cows Madrasin. The samples of this study were blood which were taken and used for analyzing DNA that includes DNA isolation, DNA amplification by using Polymerase Chain Reaction (PCR) and Restriction Fragment Length Polymorphism (RFLP) method to determine the genotype. An identification of Growth Hormone Receptor gene polymorphism is done through digesting the DNA fragment of 298 bp by the restriction enzyme AluI. The results shows that the frequency of Growth Hormone Receptor Gene of cow Madrasin allele A was 0.92 and the $\mathrm{G}$ allele was 0.08 with frequency of the A allele is higher than $\mathrm{G}$ allele.The genotype changing was found in cow Madrasin as much as 0.85 to 0.14 for the AA and AG. As a result of the study, the researcher concluded that Growth Hormone Receptor gene experienced a changing or polymorphisms in Madrasin cow and information which stated in this study be able to used as a basic for selection.
\end{abstract}

Key Words : Beef cow, genetic polymorphisms, GHR, Madrasin cow, PCR-RFLP.

\section{Pendahuluan}

Sapi Madura sebagai sapi lokal Indonesia merupakan salah satu sumber daya genetik yang ada di Indonesia. Sapi Madura mempunyai beberapa keunggulan yaitu daya adaptasinya tinggi terhadap panas dan penyakit caplak, mampu memanfaatkan pakan berkualitas rendah, mempunyai kinerja reproduksi lebih baik dibandingkan dengan sapi persilangan, serta dagingnya banyak yang disukai oleh konsumen (Suryana, 2009). Sapi Madura lebih mudah beradaptasi dengan kondisi lingkungan dan kondisi manajemen pemeliharaan di Indonesia yang sebagian besar dipelihara di peternakan rakyat.

Sapi Madura memiliki kekurangan untuk dikembangkan sebagai penghasil daging karena memiliki pertambahan bobot badan kecil untuk mencukupi kebutuhan daging di Indonesia. Beberapa wilayah di pulau Madura gencar menyilangkan sapi lokal dengan sapi Limousin melalui metode Inseminasi Buatan (IB), hasil perkawinan tersebut menghasilkan keturunan yng dikenal dengan sapi Madrasin (Diah, dkk, 2013).

Akhir-akhir ini animo masyarakat untuk melakukan persilangan sapi Madura dengan exotic breed menjadi sangat tinggi. Kenyataan di lapangan menunjukkan bahwa telah banyak dijumpai hasil persilangan sapi Limousin dengan sapi Madura di pulau Madura (Nurgiartiningsih dkk, 2010). Eksploitasi sapi Madura melalui persilangan semakin luas dan tidak terkendali dengan ternak eksotis yang akan memberikan dampak yang kurang baik pada sapi Madura yang telah beradaptasi dengan lingkungan setempat (Utomo, 2016). Akan tetapi upaya perkawinan silang (crossbreeding) perlu ditindak lanjuti dengan 
strategi pemuliabiakan yang terkendali dan berkelanjutan dalam upaya menekan efek samping crossbreeding yang mengarah perubahan mutu ternak kearah perkembangan negatif yakni akan berdampak perubahan sifat-sifat fenotip dan genetik (Wijono et al., 2004).

Studi genetik sapi Madura yang telah disilangkan dengan bangsa Limousin atau disebut juga dengan sapi Madrasin menjadi menarik untuk dilakukan guna melihat sapi yang dihasilkan mempunyai kualitas yang baik dari segi pertumbuhan. Hasil seleksi genetik dapat dijadikan acuan untuk memperoleh bibit unggul terutama untuk sapi Madrasin.

Lelana, dkk., (2003) menambahkan sejak ditemukan suatu metode pelipatgandaan DNA secara in vitro yang dikenal dengan polymerase chain reaction ( $\mathrm{PCR}$ ), maka banyak berkembang teknik molekuler berdasarkan PCR yang salah satunya adalah polymerase chain reaction-restriction fragment length polymorphism (PCR-RFLP). Pemanfaatan diagnosa berdasarkan deoxyribonucleic acid (DNA), merupakan teknologi yang efektif dan akurat sehingga akan sangat membantu program persilangan ternak (Rafalski dan Tingey, 1993).

Gen hormon pertumbuhan atau Growth Hormone $(G H)$, gen reseptor hormon pertumbuhan atau Receptor Growth Hormone $(r G H)$ dan hormon - hormon lainnya seperti Insulin Like Growth Factor 1 (IGF1) banyak digunakan dalam studi gen kandidat terhadap sifat-sifat produksi ternak, selanjutnya digunakan sebagai marker genetik dalam seleksi. Hal ini dikarenakan hormon - hormon tersebut merupakan hormon regulator pertumbuhan dan perkembangan tubuh ternak (Misrianti, 2011).

Penelitian mengenai adanya Gen Receptor Growth Hormone ( $r G H$ ) pada sapi Madrasin serta karakteristiknya belum banyak dilakukan, untuk itu menarik diteliti lebih dalam agar hasil yang didapatkan dapat dijadikan acuan untuk memperoleh sapi yang mempunyai kualitas performen yang baik.

\section{Rumusan Masalah}

Berdasarkan latar belakang penelitian diatas maka dapat dirumuskan permasalahan yaitu: Bagaimanakah Profil gen $R e$ - ceptore Growth Hormon (rGH) pada sapi Madrasin?

\section{Tujuan Penelitian}

Penelitian ini bertujuan untuk mengetahui Profil gen Receptor Growth Hormone (rGH) pada sapi Madrasin.

\section{Manfaat Hasil Penelitian}

Penelitian ini diharapkan dapat melengkapi analisis atau kajian terhadap adanya gangguan atau perubahan gen Receptor Growth Hormone (rGH) pada sapi Madrasin.

\section{Metode Penelitian \\ Sampel DNA Sapi Madrasin}

Materi utama penelitian ini adalah DNA Genom yang diperoleh dari darah sapi Madrasin sebanyak 14 sampel darah. DNA genom kemudian diekstraksi dengan menggunakan Kit DNA ekstraksi QIAamp Mini spin column untuk mendegradasi dinding sel dan mendegradasi protein dan lemak. Sampel DNA kemudian siap dilanjutkan untuk reaksi PCR.

\section{Primer rGH}

Primer yang digunakan untuk mengamplifikasi ruas gen rGH mengikuti penelitian sebelumnya dari (Zulkharnaim, 2010) tentang Identifikasi Keragaman Gen rGH pada sapi Bali dan dari (Misrianti, 2011) tentang Keragaman Gen rGH pada Sapi Perah Friesian Holstein yang diambil dari (Andreas et al, 2010) dengan produk hasil amplifikasi sepanjang 298 bp. Runutan Primer Forward 5'-CGC TTACTTCTGCGAGGTAGACGC-3' dan Reverse 5'-GTCTGTGCTCACATA GCCAC-3'

\section{Ekstraksi DNA}

Darah $10 \mathrm{ml}$ dilisiskan dengan dimasukkan ke dalam ependorf tube steril yang ditambahkan $180 \mathrm{uL}$ buffer ATL dan $20 \mathrm{uL}$ proteinase yang kemudian vortex sebentar dan diinkubasi pada suhu $56^{\circ} \mathrm{C}$ selama 1-3 jam (angkat tube dan goyang sebentar selama inkubasi). Vortex kembali selama 15 detik kemudian ditambahkan 200 uL buffer $A L$ ke dalam sampel, lalu vortex sebentar. Tambahkan ethanol 96-100\%, vortex sebentar.

Semua campuran diatas dimasukkan ke dalam tube DNeasy Mini Spin Column yang disangga oleh tube $2 \mathrm{ml}$, lalu centrifuge 
8000 rpm selama 1 menit. Pindahkan tube DNeasy Mini Spin Column diatas tube $2 \mathrm{ml}$ yang baru, kemudian tambahkan $500 \mathrm{uL}$ buffer AWI lalu centrifuge $8000 \mathrm{rpm}$ selama 1 menit. Pindahkan tube DNeasy Mini Spin Column diatas tube $2 \mathrm{ml}$ yang baru, kemudian tambahkan 500 uL buffer $A W 2$, lalu centrifuge $1400 \mathrm{rpm}$ selama 3 menit, buang tube $2 \mathrm{ml}$ yang dipakai sebagai penyangga. Kemudian Pindahkan tube DNeasy Mini Spin Column diatas tube $1,5 \mathrm{ml}$ yang baru (steril), kemudian tambahkan 200 ul buffer $A E$ tepat diatas membrane Dneasy Mini Spin Column, lalu inkubasi selama 1 menit pada suhu ruangan. Terakhir centrifuge $8000 \mathrm{rpm}$ selama 1 menit untuk mengambil DNA.

\section{Amplifikasi Ruas Gen rGH}

Amplifikasi ruas gen rGH dilakukan dengan metode PCR (Polymerase Chain Reaction). Pereaksi yang digunakan untuk amplifikasi kedua ruas gen target adalah 2 $\mu 1$ sampel DNA, primer 25 pmol, campuran dNTP $200 \mu \mathrm{M}, \mathrm{MgCl} 21 \mathrm{mM}$ dan taq polymerase 0,5 unit dan bufernya dalam larutan total $25 \mu \mathrm{l}$. Amplifikasi in vitro dengan mesin thermal cycler dilakukan dengan kondisi denaturasi awal pada suhu $94^{\circ} \mathrm{C}$ selama 5 menit, 35 siklus yang terdiri atas denaturasi pada suhu $94^{\circ} \mathrm{C}$ selama 45 detik, penempelan primer pada suhu $62^{\circ} \mathrm{C}$ selama 45 detik dan pemanjangan DNA baru pada suhu $72^{\circ} \mathrm{C}$ selama 1 menit dan pemanjangan akhir pada suhu $72^{\circ} \mathrm{C}$ selama 5 menit.

\section{Teknik PCR-RFLP}

Komposisi reaksi PCR dikondisikan pada volume reaksi 25 ul yang terdiri atas $100 \mathrm{ng}$ DNA, $0.25 \mathrm{mM}$ masing-masing primer, $150 \mathrm{uM}$ dNTP, $2.5 \mathrm{mM} \mathrm{Mg} 2+, 0.5$ Taq DNA polymerase dan $1 \mathrm{x}$ buffer. Kondisi mesin PCR dimulai dengan denaturasi awal pada suhu $94^{\circ} \mathrm{C}$ × 2 menit, diikuti dengan 35 siklus berikutnya masingmasing denaturasi $94^{\circ} \mathrm{C}$ x 45 detik, dengan suhu annealing: $65^{\circ} \mathrm{C}$ x 30 detik, yang dilanjutkan dengan satu siklus ekstensi akhir pada suhu $72^{\circ} \mathrm{C}$ selama 5 menit dengan menggunakan GeneAmp PCR System 2400 ThermoCycler (Perkin Elmer). Produk PCR kemudian di elektroforesis pada gel agarose 1,5\% dengan buffer 1x TBE (89 $\mathrm{mM}$ Tris, $89 \mathrm{mM}$ asam borat, 2 $\mathrm{mM}$ Na2EDTA) yang mengandung 100 $\mathrm{ng} / \mathrm{ml}$ ethidium bromide. Kemudian divi- sualisasi pada UV transiluminator (gel documentation system). Alel ditentukan dengan cara menginterpretasi pita (band) yang berbentuk paling jauh migrasinya ke kutub anoda sebagai alel 1 , alel 2, dan seterusnya.

Produk PCR yang diperoleh dari masing-masing gen target kemudian Dianalisis menggunakan RFLP melalui pemotongan menggunakan enzim restriksi yang memiliki situs pemotongan pada gen rGH|AluI. Sebanyak $4 \mu 1$ DNA produk PCR ditambahkan $0,5 \mu l$, selanjutnya dilakukan inkubasi selama 17 jam pada suhu $37^{\circ} \mathrm{C}$.

\section{Elektroforesis}

DNA dilihat oleh elektroforesis horisontal dengan $1,5 \%$ gel agarosa. Gel agarosa dibuat dengan mencampur agarosa ke penyangga $1 \mathrm{X}$ TAE dan mendidih di microwave selama 30 detik kemudian meninggalkannya sampai suhu $60^{\circ} \mathrm{C}$ dan menambahkan $0,12 \mathrm{ml} / \mathrm{ml}$ ethidiumbromide sehingga DNA dapat dilihat di bawah sinar ultra violet. Tuangkan cairan agarosa ke dalam wadah elektroforesis diamkan selama (15-20menit). Melakukan elektroforesis selama 90 menit (tergantung pada konsentrasi gel dan voltatio), 55 volt. DNA bisa dilihat di ruangan gelap dengan sinar ultraviolet dan mengambil gambar dengan Gel Doc 2000 menggunakan filter merah.

\section{Analisa Data}

Analisi Data pemeriksaan gen receptor Growth Hormone pada sapi Madrasin di Kabupaten Bangkalan, dengan menggunakan metode PCR yang dilanjutkan dengan metode RFLP disajikan secara deskriptif.

\section{Hasil dan Pembahasan Hasil penelitian Polymerase Chain Re- action (PCR)}

Hasil amplifikasi dari darah sapi 14 ekor Sapi Madrasin di Kabupaten Bangkalan yang dilakukan dengan metode PCR, menghasilkan 14 pita sampel DNA yang positif dengan menggunakan primer gen rGH. Hasil positif visualisasi dari elektroforesis dapat dilihat dalam Gambar 1. menunjukkan hasil pita DNA dengan panjang 298 bp yang merupakan pita spesifik gen Receptor Growth Hormone $(\mathrm{rGH})$ menggunakan marker primer Polymerase Chain Reaction, setelah diketahui 
hasil elektroforesis pada darah sapi Madrasin, kemudian di lanjutkan dengan pengujian PCR-RFLP guna mengetahui adanya perubahan gen rGH pada sapi Madrasin.

Hasil penelitian Polymerase Chain Reaction-Restriction Fragment Length Polymorphism (PCR-RFLP)

Hasil pemeriksaan amplifikasi dengan produk Polymerase Chain Reaction (PCR) yang diperoleh kemudian didigesti dengan enzim restriksi $A l u \mathrm{I}$, mendapatkan hasil pita dengan panjang 167 bp dan 81 bp pada sapi Madrasin. Hasil elektroforesis pada proses PCR-RFLP sampel darah sapi Madrasin dapat di lihat pada Gambar 2 dapat dilihat bahwa pada sampel DNA 10 dan 14 patut di duga mengalami mutasi yang disebabkan karna perubahan gen (susunan kimia gen) atau kromosom sehingga menyebabkan perubahan sifat yang diturunkan pada gen rGH.

Berdasarkan hasil amplikasi darah dengan metode Polymerase Chain Reaction (PCR) di lanjutkan dengan pembacaan elektroforesis didapatkan hasil sampel positif. Gen rGH yang terdapat pada seluruh sampel darah sapi Madrasin dapat terdeteksi oleh PCR dengan panjang produk hasil amplifikasi ruas gen rGH adalah 298 bp yang terletak pada ekson 10. Hasil penelitian ini sama dengan hasil identifikasi keragaman genetik Gen rGH pada sapi Limousin yang sebelumnya dilakukan oleh (Zulkharnaim, 2010).

Tingkat keberhasilan amplifikasi gen rGH dalam penelitian ini adalah $100 \%$. Hasil amplifikasi ruas gen rGH di visualisasikan pada gel agarose 1,5\% yang disajikan pada (Gambar 1). Suhu dan lama waktu annealing juga menentukan tingkat spesifitas hasil amplifikasi dan penyebab faktor lainnya yang berperan dalam menentukan keberhasilan amplifikasi adalah kualitas atau tingkat kemurnian DNA yang digunakan sebagai DNA template (Misrianti dkk, 2011).

Berdasarkan hasil perlakuan menggunakan PRC-RFLP ruas gen $\mathrm{rGH}$ yang diamplifikasi terdapat dua situs pemotongan $A l u \mathrm{I}$ yang dikenal dengan alel A dan alel $\mathrm{G}$, alel $\mathrm{A}$ ditandai dengan terpotongnya fragmen 298 bp menjadi dua bagian sepanjang $167 \mathrm{bp}$ dan $81 \mathrm{bp}$. Fragmen gen rGH yang memiliki situs pemotongan enzim AluI akan mengindikasikan bahwa tidak terjadi mutasi namun jika tidak terdapat situs pemotongan yang ditunjukkan dengan tidak adanya pemotongan oleh enzim AluI maka dapat dinyatakan bahwa terjadi mutasi pada situs fragmen rGH tersebut (Zulkharnaim, 2010). Keragaman pada ruas gen rGH $A l u \mathrm{I}$ diduga karena adanya mutasi atau perubahan basa tersebut menyebabkan berubahnya asam amino serine menjadi glicine.

Perubahan tersebut menyebabkan situs pemotong tidak dikenali oleh enzim Alu 1 , sehingga menghasilkan fragmen sepanjang 81 bp yang dikenal dengan alel G (Ge et al., 2003; Di Statio et al., 2005). Hasil genotyping pada sapi Madrasin ruas gen rGH menghasilkan dua macam fragmen yang terpotong yaitu genotipe AA yang ditunjukkan fragmen sepanjang 81 bp dan 167 bp dan fragmen yang terpotong menjadi satu pita disebut genotip AG yang ditunjukkan fragmen sepanjang 81 bp pada (Gambar 2). Hasil penelitian ini berbeda dengan hasil penelitian sebelumnya yang dilakukan oleh (Zulkharnaim, 2010) yaitu pemotongan fragmen gen rGH pada sapi Limousin menghasilkan tiga genotipe yaitu AA, GG, AG, genotip AA ditunjukkan fragmen sepanjang $167 \mathrm{bp}, 81 \mathrm{bp}$ dan 50 bp, dan genotip AG ditunjukkan fragmen sepanjang $167 \mathrm{bp}, 131 \mathrm{bp}, 81 \mathrm{bp}$ dan $50 \mathrm{bp}$.

Hasil analisis ruas gen rGH aluI menunjukkan bahwa frekuensi alel A $86 \%$ lebih tinggi dibanding frekuensi alel $\mathrm{G}$, Frekuensi alel A dan G pada sapi Madrasin secara berturut - turut sebesar 0,92 dan 0,08 (tabel 1) sedangkan Frekuensi genotipe AA dan AG sebesar 0,85 dan 0,14. Hasil penelitian ini berbeda jauh dengan hasil penelitian sebelumnya pada sapi Limousin yang memiliki Frekuensi alel A dan G pada sapi Limousin secara berturut - turut sebesar 0,286 dan 0,174 sedangkan Frekuensi genotipe AA dan AG sebesar 0,238 dan 0,095 (Zulkharnaim, 2010).

Berdasarkan hasil tersebut diketahui bahwa sapi Madrasin memiliki perbedaan Alel dan Genotip dengan sapi Limousin. 
Gigih Lesmana Arganata dkk.

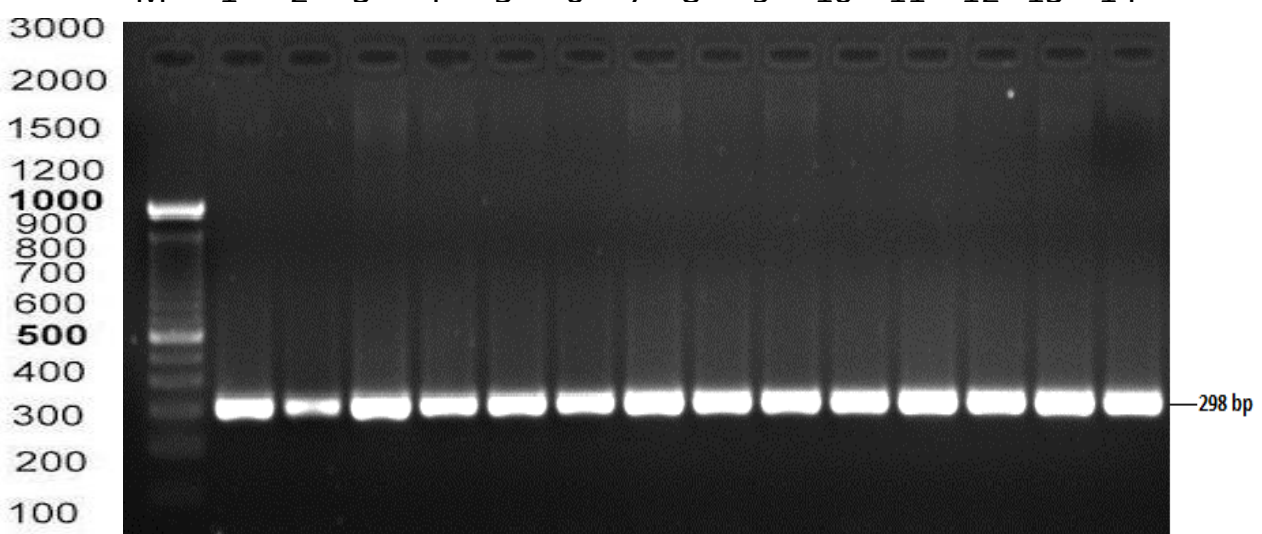

Gambar 1. Hasil Elektroforesis Polymerase Chain Reaction (PCR) pada darah sapi Madrasin. Keterangan: M=Marker DNA. 1-14 = Sampel DNA, lajur 1-14: produk PCR (298bp)

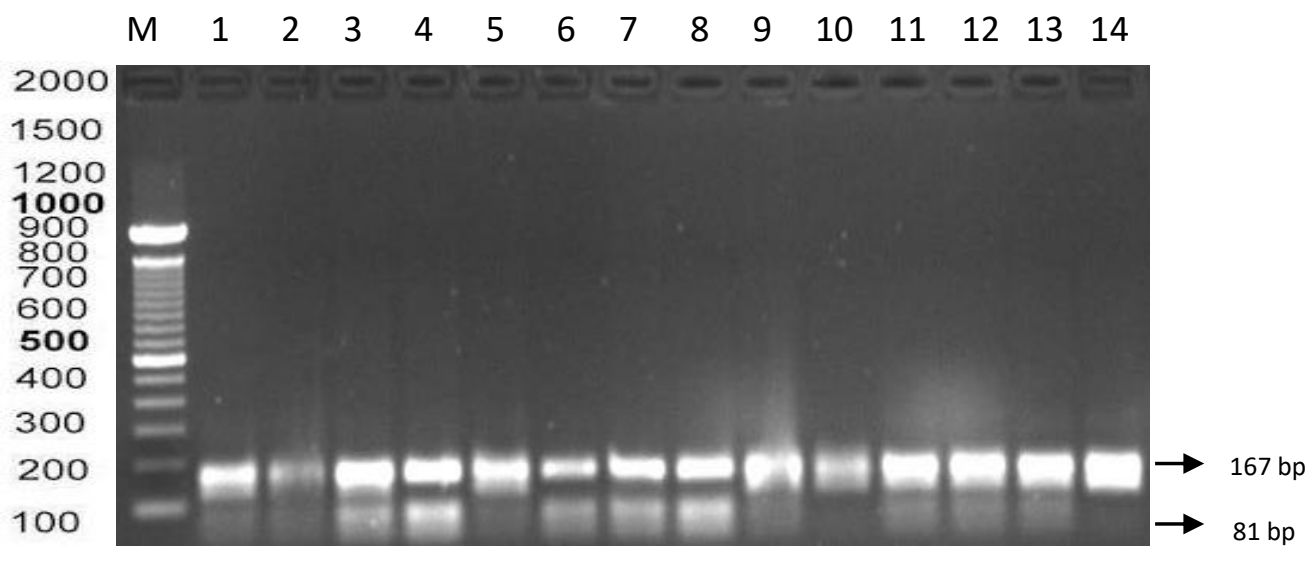

AA AA AA AA AA AA AA AA AA AG AA AA AA AG

Gambar 2 Hasil Elektroforesis PCR-RFLP AluI gen rGH sapi Madrasin.

Keterangan: $\mathrm{M}=$ Marker DNA, AA dan AG = Genotip Homozigot. 1-14 = Sampel DNA, lajur 1-9 dan 11-13 genotip AA (167bp dan 81bp), lajur 10 dan 14 genotip AG (298bp, 167bp, 81bp)

Tabel 1. Frekuensi genotip dan alel gen rGH pada sapi Madrasin (genotype and allele frequencies of Madrasin cattle). Keterangan AA, AG dan GG = genotip homozigot A dan $\mathrm{G}=$ Alel

\begin{tabular}{|l|c|c|c|c|c|c|}
\hline \multirow{2}{*}{ Bangsa (breed) } & $\mathrm{N}$ & \multicolumn{6}{|c|}{ Frekuensi genotip (genotype frequency) } & \multicolumn{2}{c|}{ Frekuensi alel (allele frequency) } \\
\cline { 2 - 7 } & & $\mathrm{AA}$ & $\mathrm{AG}$ & $\mathrm{GG}$ & $\mathrm{A}$ \\
\hline Madrasin & 14 & 0,857 & 0,142 & 0,000 & 0,925 & 0,075 \\
\hline Limousin & 21 & 0,238 & 0,095 & 0,667 & 0,286 & 0,714 \\
\hline
\end{tabular}

\section{Daftar Pustaka}

Andreas E., C. Sumantri, H. Nuraini, A. Farajallah, and A. Anggraeni. 2010. Identification of GH|Alul and GHR|Alul genes polymorphism in Indonesian Buffalo. JITAA 35:215221.

Diah S. V., T. Hartatik, dan Sumadi. 2013. Polimorfisme gen growth Hormone (GH). Buletin Peternakan. 37(2): 6773.
Ge, W., M. E. Davis, H. C. Hines, K. M. Irvin, and R. C. M. Simmen. 2003. Association of single nucleotide polymorphism in the growth hor-mone and growth hormone receptor genes with blood serum insulin-like growth factor I concentration and growth traits in Angus cattle. J. Anim. Sci. 81: 641648.

Lelana, N.E. Sutarno dan N. Etikawati. 2003. Identifikasi Polimorfisme pada 
Fragmen ND-5 DNA Mitokondria Sapi Benggala dan Madura dengan Teknik PCR-RFLP. Universitas Sebelas Maret. Surakarta. 4:1-6.

Misrianti R, C. Sumantri dan A. Anggraeni. 2011. Keragaman Gen Hormon Pertumbuhan Reseptor (GHR) pada Sapi Perah Friesian Holstein. Universitas Islam Negri Sultan Syarif Kasim. Riau. JITV. 16(4): 253-259.

Nurgiartiningsih, V. M. A. 2010. Sistem Breeding dan Performans Hasil Persilangan Sapi Madura di Madura. Jurnal Ternak Tropika. 11(2): 74-81.

Rafalski, J. A. and S.V. Tingey. 1993. Genetics diagnostics in plantbreeding RAPDs, microsatellites and machines [Review].Trends in Genetics. 9: 275280.
Suryana. 2009. Pengembangan Usaha Ternak Sapi Potong Berorientasi Agribisnis dengan Pola Kemitraan. Jurnal Litbang Pertanian, 28(1): 29-37.

Utomo budi. 2016. Mutasi Genetik Dan Penghapusan Di Sapi Madura Sebagai Hasil Persilangan. Universitas Airlangga. Surabaya. 2.

Wijono, D.B dan S Bambang. 2004. Potensi dan Keragaman Sumber Daya Genetik Sapi Madura. Lokakarya Nasional Sapi Potong dan Balai Penelitian Ternak. Pasuruan. Bogor. 14142.

Jakaria, Z. dan RR. Noor. 2010. Identifikasi keragaman genetik gen reseptor. Hormone partumbuhan (GHR|Alu1) pada sapi Bali. Med-Peternakan 33: 81-87. 